\title{
Identifikasi Bakteri Infeksi Saluran Pernafasan Bawah Non Tuberkulosis (Non TB) dan Pola Resistensinya pada Penderita Diabetes Melitus di RSUP M. Djamil
}

\author{
Virgi Anggia Lubis ${ }^{1}$, Yusticia Katar ${ }^{2}$, Elizabeth Bahar ${ }^{3}$
}

\begin{abstract}
Abstrak
Kadar gula darah yang tinggi pada pasien diabetes mellitus (DM) menyebabkan pasien ini rentan akan terjadinya infeksi, salah satunya infeksi saluran pernafasan bawah non tuberkulosis (Non TB) yang disebabkan oleh bakteri Gram negatif dan Gram positif, maka terapi pilihannya antibiotik spektrum luas. Survei awal di Bagian Penyakit Dalam RSUP M. Djamil didapatkan bahwa terapi yang dilakukan adalah terapi empiris yang mengakibatkan meningkatnya resistensi. Tujuan penelitian ini adalah mengidentifikasi bakteri penyebab infeksi pernafasan bawah non tuberkulosis dan pola resistensinya pada penderita DM di RSUP M. Djamil. Penelitian deskriptif ini dilakukan di Laboratorium Mikrobiologi FK Unand Padang dan Bagian Penyakit Dalam RSUP M. Djamil terhadap 16 pasien dengan diagnosis DM disertai infeksi saluran pernafasan bawah dari Januari sampai Februari 2014. Hasil penelitian menunjukkan Klebsiella pneumonia (56,25\%) sebagai penyebab terbanyak, diikuti Staphylococcus aureus (18,25\%), Pseudomonas aeruginosa (12,50\%), dan Streptococcus pneumonia (12.50\%). Uji resistensi menunjukkan Klebsiella pneumonia mengalami resistensi yang besar terhadap Ceftriaxone (66,63\%), Pseudomonas aeruginosa resisten terhadap Ceftriaxone dan Amoxicilin Clavulanat Acid (50\%), Staphylococcus aureus resisten terhadap Ciprofloxacin $(33,33)$, sedangkan Streptococcus pneumonia sensitif terhadap Azitromicin (100\%). Dapat disimpulkan bakteri yang ditemukan mengalami resistensi yang cukup besar terhadap beberapa antibiotik yang digunakan.
\end{abstract}

Kata kunci: diabetes melitus, infeksi saluran pernafasan bawah no TB, bakteri, resistensi

\begin{abstract}
High concentration of blood glucose in patients with diabetes mellitus cause susceptible to be infected, including lower respiratory infections non tuberculosis caused by Gram negatif and Gram positif. Treatment of these infections are broad spectrum antibiotics. The objective of this study was to indentify the causal bacteria of lower respiratory infection non tuberculous infection and the bacterial resistance patterns in patients with diabetes mellitus in RSUP M. Djamil. From the primary survey in RSUP M. Djamil Internal Medicine Department, the treatment that usually used is empirical therapy that could increase risk of bacterial resistance. This descriptive study was conducted in Microbiology laboratory Medical Faculty of Andalas University and Inpatient Care of Internal Medicine Department of RSUP M. Djamil to 16 patients with Diabetes Mellitus and lower respiratory infection from January until February 2014. Culture result showed that Klebsiella pneumonia (56,25\%) was the main cause, followed by Staphylococcus aureus (18,25\%), Pseudomonas aeruginosa (12,50\%), and Streptococcus pneumonia(12,50\%). Sensitivity test result shows that Klebsiella pneumonia has great resistance to Ceftriaxone (66,63\%), Pseudomonas aeruginosa is resistant to Ceftriaxone and Amoxicilin Clavulanat Acid (50\%), Staphylococcus aureus is resistant to Ciprofloxacin (33,33), while Streptococcus pneumonia is sensitive to Azitromicin (100\%). It can be concluded that the bacteria found had a appreciable resistance to some antibiotics used.
\end{abstract}

Keywords: diabetes mellitus, lower respiratory infection non TB, bacteria, resistance 
Affiliasi penulis: 1. Profesi Dokter FK UNAND (Fakultas Kedokteran Universitas Andalas Padang), 2. Bagian Farmakologi FK UNAND, 3. Bagian Mikrobiologi FK UNAND.

Korespondensi :Virgi Anggia Lubis, Email:

virgianggia06@gmail.com, Telp: 082174408367

\section{PENDAHULUAN}

Diabetes melitus biasanya ditandai dengan peningkatan kadar gula darah atau hiperglikemia. Kadar gula darah yang tidak terkontrol ini akan menyebabkan berbagai komplikasi, baik yang bersifat akut, maupun yang bersifat kronik. ${ }^{2}$ Pasien diabetes juga sangat rentan terhadap terjadinya infeksi, meliputi infeksi pernafasan, pielonefritis, infeksi jaringan lunak, ulkus kaki dan infeksi mukokutan. Infeksi pernafasan sangat berhubungan dengan peningkatan angka kematian, yaitu $4 x$ lipat dibandingkan dengan pasien non-diabetes. Infeksi pernafasan dapat disebabkan oleh beberapa bakteri seperti, Mycobacterium tuberculosis, Staphylococcus aureus, Streptococcus pneumonia, Legionella, Klebsiella spp, Pseudomonas aeruginosa dan $H$. influenza hal ini berhubungan dengan peningkatan angka kesakitan dan kematian. ${ }^{3}$

Infeksi saluran pernafasan bawah membutuhkan spektrum antibiotik yang sangat luas , maka idealnya pengobatan antibiotik menunggu hasil isolasi agen penyebab dan uji resistensi terhadap antibiotic. ${ }^{4}$ Survei awal yang dilakukan di Bagian Penyakit Dalam RSUP M. Djamil, terapi yang dilakukan menggunakan terapi empiris, dimana menggunakan beberapa antibiotik seperti ceftriaxone, amoxicilin clavulanate acid, ciprofloxacin, azitromycin dan meropenam. Terapi empiris ini dapat meningkatkan resiko terjadinya resistensi terhadap antibiotik spektrum luas, maka perlu adanya identifikasi bakteri Infeksi Saluran Pernafasan Bawah
(ISPB) non tuberkulosis (non TB) dan resistensinya pada pasien Diabetes Melitus terlebih dahulu sebelum pemberian pengobatan.

Tujuan penelitian ini adalah mengidentifikasi bakteri penyebab infeksi pernafasan bawah non tuberkulosis (non TB) dan pola resistensinya pada penderita diabetes mellitus (DM) di RSUP M. Djamil.

\section{METODE}

Penelitian telah dilaksanakan di Laboratorium Mikrobiologi Fakultas Kedokteran Universitas Andalas Padang dan instalasi rawat inap Penyakit Dalam RSUP M. Djamil. Waktu pelaksanaan penelitian dilakukan dimulai dari pembuatan proposal hingga hasil penelitian dari Juni 2013 hingga April 2014.

\section{HASIL}

Berdasarkan hasil penelitian didapatkan hasil pada tabel di bawah ini

Tabel 1. Pola kuman ISPB pada penderita diabetes

\begin{tabular}{lll}
\hline Bakteri & Jumlah & Persentase \\
\hline Klebsiella pneumonia. & 9 & $56,25 \%$ \\
Pseudomonas aeruginosa & 2 & $12,50 \%$ \\
Staphylococcus aureus & 3 & $18,75 \%$ \\
Streptococcus pneumonia & 2 & $12,50 \%$ \\
\hline Total & 16 & $100 \%$ \\
\hline
\end{tabular}

Pada Tabel 1 ditemukan bakteri terbanyak penyebab infeksi saluran pernafasan bawah yaitu Klebsiella sp 56,25\%, diikuti Staphylococcus sp 18,75\%. Pseudomonas sp 12,5\%, dan Streptococcus pneumonia $12,5 \%$.

Tabel 2. Pola resistensi bakteri ISPB yang ditemukan terhadap beberapa antibiotik

\begin{tabular}{|c|c|c|c|c|c|c|c|c|c|c|}
\hline \multirow{3}{*}{ Bakteri } & \multicolumn{10}{|c|}{ Antibiotik } \\
\hline & \multicolumn{2}{|c|}{ AMC } & \multicolumn{2}{|c|}{ CIP } & \multicolumn{2}{|c|}{ CRO } & \multicolumn{2}{|c|}{ MEM } & \multicolumn{2}{|c|}{ AZM } \\
\hline & $\mathrm{R}(\%)$ & $\mathrm{S}(\%)$ & $\mathrm{R}(\%)$ & $\mathrm{S}(\%)$ & $\mathrm{R}(\%)$ & S (\%) & $\mathrm{R}(\%)$ & $\mathrm{S}(\%)$ & $\mathrm{R}(\%)$ & $\mathrm{S}(\%)$ \\
\hline Klebsiella pneumonia & 33,33 & 66,67 & 44,44 & 55,56 & 66,67 & 33,33 & 0 & 100 & - & - \\
\hline Pseudomonas aeruginosa. & 50 & 50 & 0 & 100 & 50 & 50 & 0 & 100 & - & - \\
\hline Staphylococcus aureus. & 0 & 100 & 33,33 & 66,67 & 0 & 100 & 0 & 100 & 0 & 100 \\
\hline Streptococcus pneumonia. & - & - & - & - & - & - & - & - & 0 & 100 \\
\hline
\end{tabular}

Ket: $\mathrm{AMC}=$ Amoxicilin Clavulanat Acid, CIP $=$ Ciprofloxacin, $\mathrm{CRO}=$ Ceftriaxone, MEM = Meropenem, AZM = Azitromicyn 
Pada Tabel 2 dapat diketahui bahwa bakteri Klebsiella pneumonia mengalami resistensi yang besar terhadap Ceftiaxone yaitu sebesar 66,67\%, diikuti Ciprofloxacin 44,44\%, Amoxicilin Clavulanate Acid 33,33\% dan masih sensitif terhadap Meropenem. Bakteri Pseudomonas sp rmengalami resisteni yang sama terhadap Ceftiaxone dan Amoxicilin Clavulanate yaitu sebesar $50 \%$ tetapi masih sensitif terhadap Ciprofloxacin dan Meropenem. Bakteri Staphylococcus sp mengalami resistensi terhadap Ciprofloxacin sebesar 33,33\% dan masih sensitif terhadap Amoxicilin Clavulanate Acid, Ceftiaxone, Meropenem dan Azitromycin. Bakteri Streptococcus pneumonia masih sensitif terhadap Azitromycin. Berdasarkan data zona hambat yang digunakan yaitu tabel CLSI (Clinical Laboratory Standarts Institute) daya hambat dari antibiotik Azitromycin hanya terdapat untuk bakteri Streptococcus pneumonia dan Staphylococcus aureus. Pada antibiotik Amoxicilin Clavulanate Acid, Ciprofloxacin, Ceftriaxone, Meropenem tidak terdapat data daya hambat terhadap Streptococus pneumonia.

\section{PEMBAHASAN}

Jumlah sputum yang diteliti dari pasien diabetes mellitus yang mengalami infeksi saluran pernafasan bawah sebanyak 16 sputum. Hasil penelitian ditemukan bakteri Klebsiella pneumonia sebagai penyebab terbanyak infeksi saluran pernafasan bawah diikuti Staphylococcus aureus, Streptococcus pneumonia, dan Pseudomonas aeruginosa. Penderita diabetes rentan mengalami infeksi dikarenakan, dari beberapa penelitian diketahui terjadi defisiensi Complement 4 (C4) pada penderita diabetes mellitus. Sistem Complement merupakan salah satu mekanisme penting yang bertanggung jawab terhadap humoral immunity pada seseorang. Defisiensi C4 ini dapat mengakibatkan terjadinya gangguan terhadap aktifitas komplemen seperti fagositosis (opsonisasi) dan khemotaksis. ${ }^{5}$ Seorang penderita diabetes mellitus akan mengalami penurunan imunitas dan rentan terinfeksi. Bakteri Klebsiella pneumonia merupakan bakteri yang berada di saluran pernafasan pada lebih $5 \%$ individu normal. Bakteri ini dapat menyebabkan infeksi pernafasan bawah bila seseorang tersebut mengalami sistem imun yang lemah seperti penderita diabetes mellitus. ${ }^{6}$ Bakteri ini merupakan patogen bagi penderita yang dirawat dirumah sakit. ${ }^{7}$ Dalam pelayanan kesehatan bakteri ini dapat menyebar melalui kontak langsung misalnya dari pasien ke pasien, melalui tangan yang terkontaminasi personil kesehatan atau orang lain. Tidak hanya itu, penderita dapat terkena infeksi Klebsiella pneumonia dari alat-alat kesehatan, seperti ketika mereka menggunakan ventilator, infus intravena, kateter ataupun luka dari pembedahan. ${ }^{8}$

Bakteri penyebab infeksi pernafasan bawah berikutnya adalah Staphylococcus aureus, bakteri ini dapat menginfeksi pada orang-orang yang memiliki faktor resiko, yaitu orang-orang yang dalam keadaan kronik seperti penderita diabetes. ${ }^{9} \quad$ Bakteri Streptococcus pneumonia juga merupakan penyebab infeksi saluran nafas bawah yang ditemukan. Pada dasarnya Streptococcus pneumonia terdapat di saluran nafas atas pada sekitar 5-40\% manusia namun dapat menjadi patogen bila bakteri ini berkembang dan tumbuh banyak, sehingga dapat menyebabkan pneumonia, sinusitis, otitis, bronkhitis, bakterimia, meningitis, dan infeksi lain. ${ }^{10}$ Selain itu bakteri Pseudomonas aeruginosa merupakan penyebab 10-20\% infeksi nasokomial dan saluran nafas bawah. ${ }^{11}$ Patogenesis Pseudomonas aeruginosa bersifat multifaktorial dan kompleks dimana bakteri ini bersifat invasif dan toksigenik. Bakteri ini juga merupakan bakteri patogen oportunistik, dimana menyebabkan infeksi pada individu dengan imunitas yang menurun. ${ }^{12}$

Hasil uji resistensi yang dilakukan terhadap bakteri Klebsiella pneumonia, bakteri ini mengalami resistensi yang tinggi terhadap antibiotik Ceftriakson $(66,67 \%)$. Bakteri Klebsiella pneumonia merupakan bakteri yang menghasilkan enzim ESBL (Extended Spectrum Beta Lactamase), enzim ini dapat merusak cincin beta laktam dan menimbulkan resistensi terhadap antibiotik golongan beta laktam seperti penisilin dan sefalosporin. ${ }^{13}$

Pada uji resistensi Pseudomonas aeruginosa, bakteri ini mengalami resistensi yang sama terhadap antibiotik Ceftriakson (50\%) dan Amoksisilin Clavulanate (50\%), tetapi masih sensitif terhadap antibiotik Ciprofloksasin dan Meropenem. 
Bakteri Klebsiella pneumonia, bakteri Pseudomonas aeruginosa membawa enzim beta laktamase pada kromosomnya dan bakteri akan mejadi resisten terhadap sefalosporin dan penisilin jika bakteri memproduksi enzim dalam jumlah yang cukup besar. ${ }^{14}$ Hasil uji resistensi Staphylococcus aureus ditemukan bahwa resistensi hanya terjadi pada antibiotik Ciprofloksasin (33,33\%), dan masih sensitif terhadap antibiotik Amoksisilin Clavulanate Acid, Ceftriakson, Azitromisin, dan Meropenem. Mekanisme resistensi bakteri Staphylococcus aureus yaitu dengan mengubah tempat ikatan terhadap antibiotik tersebut. ${ }^{15}$ Bakteri Streptococcus pneumonia masih sensitif terhadap Azitromycin. Berdasarkan data zona hambat yang digunakan yaitu tabel CLSI (Clinical Laboratory Standarts Institute) daya hambat dari antibiotik Azitromicin hanya terdapat untuk bakteri Streptococcus pneumonia dan Staphylococcus aureus, pada antibiotik Amoxicilin Clavulanate Acid, Ciprofloxacin, Ceftriaxone, Meropenem tidak terdapat data daya hambat terhadap Streptococcus pneumonia

Dari kelima antibiotik yang digunakan sebaga terapi di rawat inap penyakit dalam RSUP antibiotik Meropenem masih memiliki sensitivitas yang cukup tinggi. Meropenem merupakan antibiotik beta laktam golongan Karbapenem. Karbapenem merupa-kan betalaktam yang struktur kimianya berbeda dengan penisilin dan sefalosporin Antibiotik ini memiliki spektrum aktvitas yang sangat luas meliputi Gram positif, bakteri Gram negatif, serta bakteri anaerob. ${ }^{15}$

Tingkat resistensi antibiotik berhubungan dengan konsumsi antibiotik nasional dan penggunaan antibiotik sebelumnya pada setiap individu. Karena sering mengalami infeksi, pasien diabetes akan terpapar antibiotik lebih banyak, sehingga dapat menyebabkan peningkatan tingkat resistensi antibiotik. Farmakokinetik antibiotik dapat terganggu pada pasien DM. Gangguan pembuluh darah perifer menyebabkan penetrasi antibiotik pada jaringan infeksi menurun. ${ }^{16}$

Dari 16 pasien yang diperiksa, dilakukan check terhadap pengobatan yang diberikan, ditemukan 5 pasien yang terinfeksi bakteri Klebsiella pneumonia dan Pseudomonas aeruginosa mendapatkan pengobatan antibiotik ceftriaxone dan dari hasil penelitian bakteri tersebut telah resisten ceftriaxone.

\section{KESIMPULAN}

Distribusi bakteri penyebab infeksi saluran pernafasan bawah pada pasien diabetes mellitus dari penelitian identifikasi bakteri di rawat inap penyakit dalam RSUP M. Djamil yang terbanyak adalah bakteri Klebsiella pneumonia, diikuti Staphylococcus aureus, Pseudomonas aeruginosa, dan Streptococcus pneumonia.

Pola resistensi yang diperoleh dari uji resistensi ditemukan:

\section{Klebsiella pneumonia}

Mempunyai resistensi yang tinggi terhadap antibiotik Ceftriaxone dan masih sensitif terhadap Meropenem.

2. Pseudomonas aeruginosa

Mempunyai resistensi yang sama terhadap Ceftriaxone dan Amoxicilin Clavulanate Acid tetapi masih sensitif terhadap Ciprofloxacin dan Meropenem.

3. Staphylococcus aureus

Mempunyai resistensi tehadap Ciprofloxacin dan masih sensitif terhadap Amoxicilin Clavulanate Acid, Ceftriaxone, Azitomycin, dan Meropenem.

\section{Streptococcus pneumonia}

Masih sensitif terhadap Azitromycin.

\section{DAFTAR PUSTAKA}

1. Price SA, Wilson LM. Patofisiologi: konsep klinis proses-proses penyakit vol .2. Alih bahasa Brahm $\cup$ Pendit et al; Alih editor bahasa Indonesia: Hartanto H et al. Jakarta: EGC, 2005: 1202-11.

2. Regina. Gejala diabetes melitus. Jurnal Diabetes. 2012.

3. Zarbock S. Infections in patients with diabetes. Medscape Article. 2005.

4. WHO. Use Antibiotics rationally [serial online]. 2007 (diunduh 4 Agustus 2013). Tersedia dari: URL: HYPERLINK http://www.ino.searo.who.int/ LinkFiles/Home WHD11-Messages-11 03 31-

Faqs.pdf

5. Casqueiro J, Alves C. Infections in patient with diabetes melitus: a review of pathogenesis. Indian Journal of Endocrinology. 2012;16(1):S27-S36. 
6. Subekti R. Pola kepekaan bakteri gram negatif pada penderita infeksi saluran napas bawah terhadap seftriakson di laboratorium mikrobiologi klinik departemen mikribiologi FKUI Tahun 20012005 (skripsi). Jakarta: Universitas Indonesia; 2009.

7. Microbewiki. Klebsiella Pneumoniae [serial online]. 2011 (diunduh 31 Juli 2013). Tersedia dari: URL: HYPERLINK http://www.microbewiki.kenyon.edu/ index.php/Klebsilla pneumoniae

8. Obiamiwe U. Klebsiella infections treatment \& management [serial online]. 2013 (diunduh 17 Maret 2014). Tersedia dari: URL: HYPERLINK http://emedicine.medscpe.com/article/219907treatment.

9. Kumar V. Buku ajar patologi. Edisi ke-7. Jakarta: EGC; 2007.

10. Brooks G, Butel J, Morse S. Mikrobiologi Kedokteran. Edisi ke-23. Alih bahasa Hartanto $\mathrm{H}$. Editor edisi bahasa Indonesia, Elferia RN. Jakarta: EGC; 2007.
11. Karsinah. Batang negatif gram. Dalam: Syahrurachman A et al, editor (penyunting). Buku ajar mikrobiologi kedokteran. Jakarta: Bina rupa Aksara Publisher; 2009. hlm.185.

12. Lessnau KD. Pseudomonas aeruginosa Infections. Medscape Article. 2014.

13. Herwana E, Yenny, Pudjiaji L, Surjawidjaja J, Murad Lesmana. Prevalence of extended spectrum beta-lactamase in klebsiella pneumonia. Jurnal Universa Medicina. 2008;.27(3).

14. Sjahrurachman A. Cara genetis untuk menentukan kepekaan bakteri terhadap antibiotik. Jurnal CDK. $2011 ; 38(7)$.

15. Syarif A. Farmakologi dan terapi. Jakarta: Fakultas Kedokteran Universitas Andalas; 2009.

16. Boyanova L, Miltov I. Antibiotic resistance rate in causative if infections in diabetic patient. Medscape Article. 2013;11(4):411-20. 